\title{
Cultural relict plants - a living heritage
}

\author{
Svein Øivind SolberG*, Line Breian*, Lena Ansebo*, Erik Persson*
}

\begin{abstract}
Cultural relict plants are remaining populations of plants once introduced for cultivation and use. The plants have survived, even though the population is no longer actively maintained. Cultural relict plants can be found in the close surroundings of historical places such as monastery ruins, churches, castles, fortresses, manors, old farms and villages. The plants are part of a living heritage, but the responsibility tends to fall between different perspectives - between the conservation of buildings, objects and immaterial knowledge (cultural heritage) and conservation of nature (natural heritage). In this article we debate the value of such plants as parts of a place. We list potential species and findings from a project with focus on the Arctic region in the Nordic countries. We furthermore emphasise the need for trans-disciplinary approaches to secure the habitat and increase awareness about cultural relict plants.
\end{abstract}

Key words: Cultural relict plants, cultural heritage, natural heritage, ethno-botany, trans-disciplinary, conservation, in situ, seed bank.

\section{BACKGROUND}

The importance of biodiversity in the heritage debate was highlighted in Nordic Museology in 2010 (Hafsteinsson 2010: 2). Our contribution must be seen as a follow-up to his challenge. As we all know, plants were introduced to our region and were cultivated to be applied in food and medicine, but also for the production of oils, fibres, colours and heat, or to be used as ornamentals, in beekeeping or for various other purposes. Many plants are believed to have been introduced to the Nordic region in medieval times. However, very little of this process is documented, and a lot of questions are still to be answered. Lange (1966) pointed out that certain plant species tend to be connected to medieval sites, and says that the same observation also was reported by Jens Lind (1918). By reading books as the botanical masterpiece from Martinsson \& Ryman (2008) with its reprints of Rudbeck's old drawings from the last part of the 17 th century, we see that a wide range of plants were used in old days. Medieval sources from the Nordic area are few, and the work of Henrik Harpestreng is the only we have seen described (see Molbech 1826). But we can 


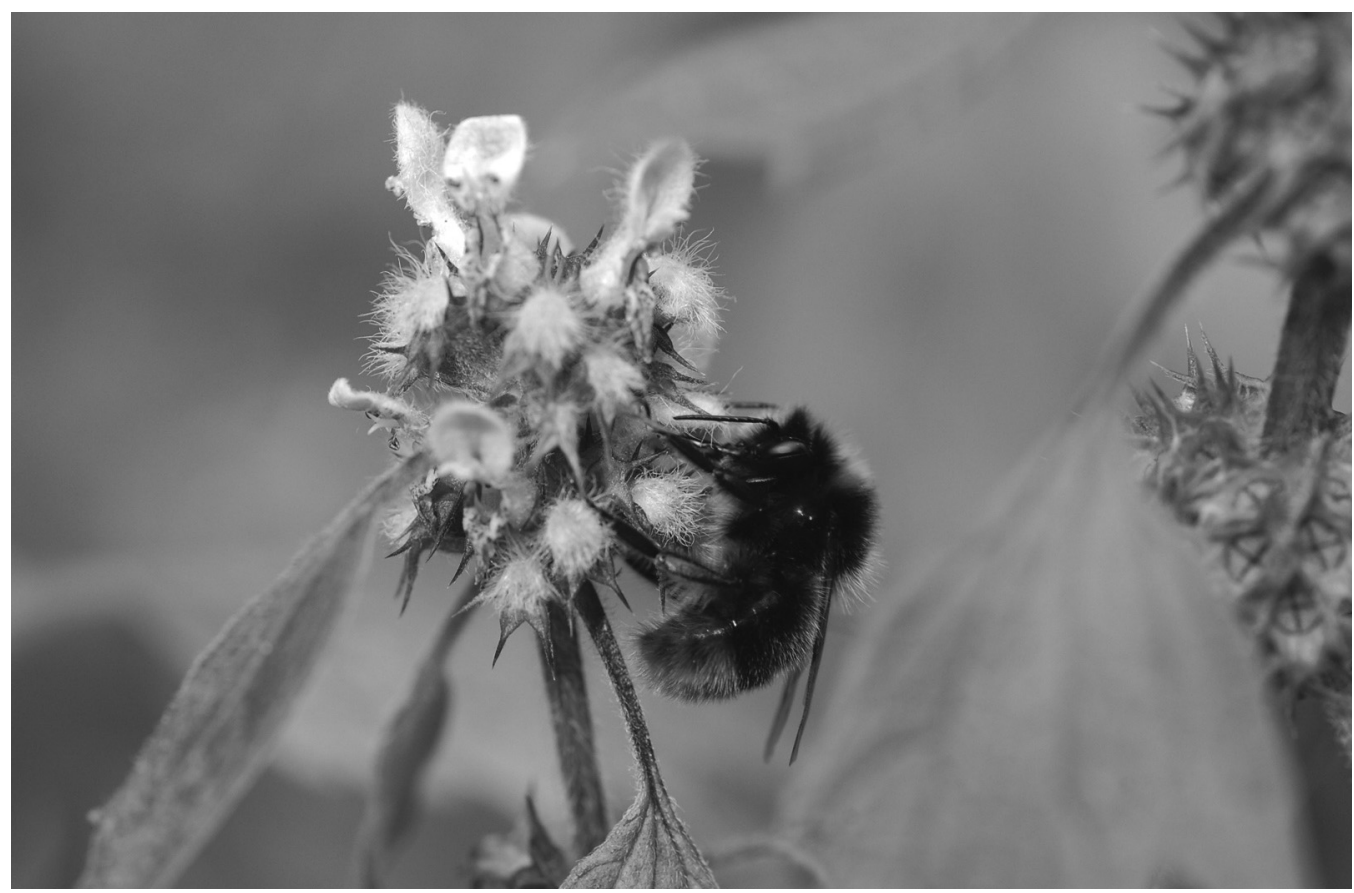

Fig. 1. Leonurus cardiaca (Tunlovehale/Hjärtstilla) is rare. The plant was used as medicine until the last part of the 18th century. Relict populations can be found in villages or on farms in Southern Scandinavia. The plant species is endangered and red-listed in Norway and in Sweden. Photo: S.Ø. Solberg.

assume that many plants were introduced and some of them may have survived on the place (Lange 1999). In the further article we call such plants for Cultural Relict Plants (CRP).

Cultural relict plants are defined as remaining populations of plants once introduced for cultivation. We argue that CRPs need to fulfil both: (A) is a remaining population of a cultivated plant species, and (B) is connected to a specific cultural place. To be called CRP, both $\mathrm{A}$ and $\mathrm{B}$ must be true. Without $\mathrm{B}$ we do not have a CRP.

The idea of cultural relict plants has been published by Bernt Løjtnant (1995, 2006,
$2007 \mathrm{a}, 2007 \mathrm{~b})$, who studied more than 2600 medieval cultural places in Denmark (churches, monasteries, castles, fortresses, manors, farms, mills, farmer villages and fishing villages) and listed CRP from approx. 270 species. His study was based on a combined knowledge of botany and local history. Løjtnant furthermore distinguished between CRP from species introduced to Denmark from abroad and CRP from species indigenous to Denmark, but equally also used for cultivation. The distinction reflects the fact that plants were brought home from the wild (e.g. from the mountain and the forest) as well 
as from other countries (e.g. from Germany, France or England). Løjtnant (2007a: 11) furthermore claims that the monasteries were not the only actor in introducing new species to Denmark - kings, soldiers, businessmen and other travellers also brought plants home. From medieval times onwards, many new species came to Denmark, and in the following article we link the CRP back to medieval times, but without a more specific timeframe. Only by extensive research in archaeology and molecular biology (using DNA analyses, for example), a better understanding of the introduction history can be made.

Plants have different mechanisms to survive in a certain place. A tree can stand for hundreds of years and survive from one year to another. An annual or bi-annual plant will die within one or two years, but leave seeds for a new generation. Seeds can also remain dormant in the soil for many years. One mechanism of survival is to produce dormant seeds that germinate years after their release; another is to survive by producing new shoots from a network of roots at various layers down in the soil.

The main objective of our article is to increase the awareness of cultural relict plants. Furthermore we would like to discuss the conservation responsibility and present ways of conserving plants as part of the heritage. We must see CRP as part of cultural places, and accordingly as part of the cultural heritage.

\section{NATURAL HERITAGE VERSUS CULTURAL HERITAGE}

Natural heritage involves disciplines of natural sciences, such as conservation management, biology and ecology. Threatened species are identified, monitored and presented in various

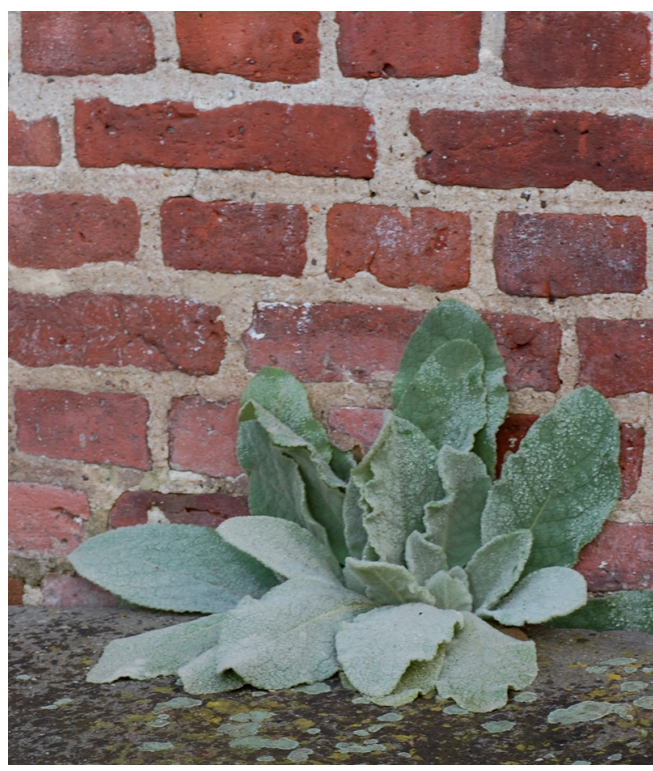

Fig. 2. Verbascum Thapsus (Filtkongslys/Kugsljus) is quite common, and can be found as cultural relict plants close to buildings. The plants are bi-annual, flowering the second year. Photo: S. Ø. Solberg.

lists (red lists) and eco-systems are protected by legislation (national parks, nature reserves). The conservation is focused on species level. Plants of red-listed species are even kept in botanical gardens and seed banks, such as the Millennium Seed Bank and Kew Garden (United Kingdom). Botanical gardens increasingly see conservation as one of their main missions in society.

Cultural heritage is generally handled in the disciplines of cultural sciences, such as archaeology and anthropology, where immaterial knowledge and objects are kept in libraries, archives and museums, or are protected on site. Bio-cultural heritage (or bioheritage) is a relatively new term used to highlight awareness about plants, animals and 
landscapes (CBD 1992). Here the population level has an importance; a small population may be valuable and threatened even though the species is generally considered nonthreatened.

In Sweden a biodiversity center has been established with projects on how landscapes are influenced by human activity (CBM 2013) and with a specific programme about local and traditional knowledge and the use of biological diversity (Tunón \& Byström 2007). In Norway biodiversity and cultural landscape projects are also developed (Direktoratet for Naturforvaltning 2013). The focus is on the cultural landscape, old meadows and on traditional use of plants. The idea of CRP conservation has not been part of these projects.

CRP furthermore tends to fall outside the mandate of conservation of genetic resources used for food and agriculture. Nordic Genetic Resource Center runs a seed bank, where more than 30,000 seed samples from food crops are stored in freezers for future use for breeding and research. The seed samples are mostly old cultivars of cereals, vegetables or forage crops, but also breeding lines. A back-up of the material is sent to Svalbard, where Norway hosts the Global Seed Vault, a facility open for all the seed banks in the world. Collects of CRP are stored in the seed bank, but only some populations from some places (see later). CRP should be preserved in their natural habitat as the plants are part of the place and the heritage of the place, while seed bank conservation should only be a supplement or a back-up. Gene bank accessions can also be used for distribution according to the international regulations on plant genetic resources (ITPGRFA 2002).

Cultural relict plants belong both to the cultural heritage and the natural heritage.

They tend to fall between two stools - between the conservation of objects and immaterial knowledge and conservation of nature. CRP also tends to fall outside the conservation of food plants.

Some CRPs might be found in large populations and behave like weeds (and are even called "weeds"), and need no protection. Other populations are threatened by extinction. According to our experience, most CRPs can be found in small groups, often with from ten to some hundred individuals per habitat. The distance to the next habitat can vary a lot. Theoretical models say that the minimum viable population size is in the range from some hundred to some thousand individuals in closed systems, depending on the type of organism and its systems of avoiding inbreeding depression. Applying this knowledge to CRP, we would say that many of the populations are endangered and are in an urgent need of protection.

\section{LEGISLATION AND REGULATIONS}

Can legislation and regulations clarify more about who is responsible for the protection of CRP? In the following we use Norway as an example. In Norway, a common law for the conservation of cultural heritage, natural heritage and museums was suggested as early as in 1971-72 (Stortingsmelding nr. 93), but has not yet been realised. Denmark, however, has had museum legislation (Museumsloven) since 2006, outlining the responsibilities of cultural versus natural institutions. However, nothing was said explicitly about cultural plants. In Norway, Kulturloven (LOV $2007-$ 06-29 nr 89, 2007) includes cultural heritage in $\$ 2$, but nothing was said about nature, 
28 landscape or plants. The Cultural Heritage Act (1978: $\$ 20$ ), under the heading of cultural environment, states that "A cultural environment may be protected by the King in order to preserve its value to cultural history." An example of the application of $\$ 20$ is in the conservation of the Sør-Gjæslingan area in Vikna, Nord-Trøndelag, where cultural plants are explicitly mentioned in the regulation of the area. The removal of cultural plants is not permitted, and all planting must be done by using traditional, local plants (FOR-2010-1001-1319).

The Norwegian Ministry of the Environment (2013) is furthermore, with its target area 6 Valuable Cultural Heritage and Cultural Environment, responsible for: "Developing strategies and policies within the entire field of cultural heritage. Important topics are archaeology, building protection and cultural heritage as a resource in developing urban areas and villages, vessel protection, cultural environments and cultural landscapes." CRP could be read into this. However, the awareness of CRP must be identified by governmental bodies and stakeholders involved in the protection of cultural environments.

\section{Focus ON ARCTIC CRPS}

A project was started in 2010 focusing on the Arctic region. The work was financed by The Nordic Council of Ministers' Arctic Program and by Nordic Genetic Resource Center, and the project is presented by Persson (2013, publication in progress) and Persson et al. (2013, also in progress). In the following section we highlight some findings.

\section{Awareness about CRP}

One of the main goals of the project was to connect the national experts in a Nordic network, so that the knowledge about CRPs can be spread and utilised. A conference took place in July 2012 in Egilsstaðir (Iceland). One of the outcomes of the conference was a decision to produce and maintain a web page that can function as a forum for information dissemination and discussion of future work related to CRPs. It was furthermore seen as important to spread knowledge about CRPs to practitioners and policy makers. Some CRPs are particularly vulnerable, and they are sensitive to management practices and environmental changes. It is therefore important to create an understanding of measures that need to be taken to protect and maintain populations. In order to facilitate this, it was decided to produce two pamphlets. The first: Reliktplanter - levende fortidsminner (Solberg et al. 2012) gives an overview of the concept of CRP, presents national examples, and explains why CRPs are important and how they can be conserved. A second pamphlet is aimed at the practitioners - the organisations responsible for historical sites as well as the workers maintaining the cultural environments. This pamphlet will include a management guide showing good examples of how historical sites can be managed with simple, cost-effective methods to create a beneficial environment for living relics. This pamphlet will be finished in the spring of 2013. Both pamphlets will also be available from the website for the Nordic Genetic Resource Center. In addition, we should mention that a significant work on plant names from the medieval period has been published by Inger Larsson (2010).

Traditional use of plants in the Arctic region - some key interviews

During the project period we carried out in- 
depth interviews with several persons linked to the plant community of the Arctic region. These included Anne Sofie Hardenberg, author and food ambassador in Greenland, and with knowledge about Inuit traditions, Greta Huuva, from the Sami Education Centre, Sweden, with extensive knowledge about Sami traditions, and Brynhild Mørkved, from Tromsø Museum, studying historical plants and gardens in northern Norway.

Anne Sofie Hardenberg highlighted Angelica archangelica ("kvann") as being used for many purposes by the Inuit people in Greenland, Thymus sp. ("timian") used for purposes that included tea, and Rhododendron groenlandicum ("grønlandspost") that was forgotten, but is now undergoing a renaissance in cooking. Many other plants have been used, including seaweed and flowering plants. The plants were collected from the wild. The locations of the plants are mainly in the South Greenland. As far as Anne Sofie Hardenberg knows, no cultivation of the plants took place, nor does she have any information about protection measures of threatened populations.

Greta Huuva emphasised that the Sami people have used plants like Angelica archangelica ("kvanne"), as well as Rumex acetosa ssp. lapponicus ("fjällängssyra"), Oxyria digyna ("fjällsyra"), Alchemilla, A. alpine ("fjällkåpa"), Epilobium angustifolium ("mjölkört"), Achillea millefolium ("röllika"), and berries of different species. A special traditional dish that the Sami people have very much relied upon, "gompan", consists of a fermented herb mixture including Angelica achangelica, Rumex acetosa, and Epilobium angustifolium. These plants were not cultivated by the Sami people, but collected from the wild. However, populations of valuable species were protected, because it was important to not use up everything.
Where Sami people and new settlers met, there were conflicts, but also some integration and exchange of cultures and traditions. Cultivation on smaller scale took place of crops such as potato, onion and turnips, as well as grains for the animals. Wild sedge and marsh meadows were cut for hay.

Brynhild Mørkved emphasised that many species were important in the old gardens in Northern Norway. One interesting plant is Allium victorialis ("seiersløk"), a species from the Alpine region in South Eastern Europe, where it is used as food, medicine and as a talisman. It does not grow wild in the Nordic countries, but is cultivated in gardens. On Vestvågøy in Lofoten Allium victorialis is very common in gardens and churchyards, from where it is also naturalised. It would be very interesting to study these populations more thoroughly. Are they relics from the Viking times? The national programme for plant genetic resources in Norway is involved in the conservation of garden plants in field gene banks, also called clonal archives, such as Tradisjonshagen in Tromsø. Local museum gardens can also serve as a back-up for the plants. Brynhild Mørkved explained that in situ conservation is very difficult since this often concerns private gardens, and thus it is not easy to arrange long-term conservation.

\section{Potential CRPs in the Arctic}

Bernt Løjtnant is listing CRPs from populations of approx. 270 species relevant for Denmark (complete list not published, personal communications). We have compared his list to flora observations in other Nordic countries and regions, with references to Flora of Iceland (www.floraislands.is), Íslenzkar jurtir (Löve 1945), Gronlands flora (Böcher et al. 1978), Nya nordiska floran (Mossberg \& Stenberg 
2003), Den virtuella floran (linnaeus.nrm.se), Planter og tradisjon (Høeg 1976), and Guldager Christiansen \& Fosaa (2009). What we see is that the number of potential CRP species decreases significantly in Northern Scandinavia compared to Denmark, with numbers as 270 species in Denmark to around 60 in Northern Norway, 50 in Northern Sweden/ Finland, 22 in Iceland, 18 in the Faroe Islands, and 16 in Greenland (Table 1). What we also see is that some species that are not listed as potential CRPs in Denmark might be so in other regions. Some of the species frequently found wild in one region, and not necessarily cultivated, might have been introduced for cultivation into other regions, and thus becoming a CRP in the new places. One example is caraway (Carum carvi) on Iceland. The introduction of caraway to Iceland is known to have occurred in the mid 17ths century by Gísli Magnússon (1621-1696) who settled in Hlídarendi in the South of Iceland, and allegedly brought seeds from Denmark or the Netherlands (Benediktsson 1939). In Hliðarendi, caraway can still be found growing semi-wild in the meadows (recently collected and conserved as accession NGB20109). Later the caraway plant has spread throughout the country of Iceland. Hence, a botanical list of potential CRPs species should be connected more to a region than a country or a group of countries. CRPs are connected to a local or regional culture. Knowledge about the local traditional use of plants and knowledge on how people collected or cultivated plants would add value to our and others studies. Inventories have been carried out at monastery ruins in Norway (Åsen 2009) and on Iceland (Lundquist 2010, Larsson et al. 2012), as well as at the castle ruins at Hammershus on Bornholm (Bjerregaard 2013).

\section{CONSERVATION ACTIONS}

The survival of CRPs is not only linked to the plants themselves, but also to the environment as influenced by human activity. Some important influences affecting the plants and their environments are:

- Destruction of natural habitat - urbanisation, construction, drainage (for example)

- Management - grass cutting, intensive cleaning, grazing, herbicides (for example)

- Flora hunters - digging up, collecting, replanting

- Lack of knowledge and awareness.

All these require action to be taken to protect and maintain populations (Løjtnant et al. 1995). Awareness of what cultural relict plants are, and what kind of species they are, is the first step in a process of protecting the plants. A next step is a management plan and furthermore some kind of additional protection action or regulations.

Conservation of cultural relict plants is best done in situ, which means at the place of origin. Conservation in gene banks can be a supplement to in situ conservation, as seeds can survive for many years in freezers and collected seeds can be used for multiplication, distribution and restoration (Poulsen et al. 2010: 86-88). So far the Nordic Genetic Resource Center has collected and stored 300-400 seed samples of CRPs, most from selected places in Denmark, but recently also from locations in Sweden and Norway. A list of the locations includes:

- Jylland (Kalø, Agri, Kollerup, Mols, Mariager, Mols - Dråby, Esby, Bosby, Strandsø, Eens kirke, Fiskbæk kirke, Høegholm, Ørslev kloster, Kvols, Spøtterup). 


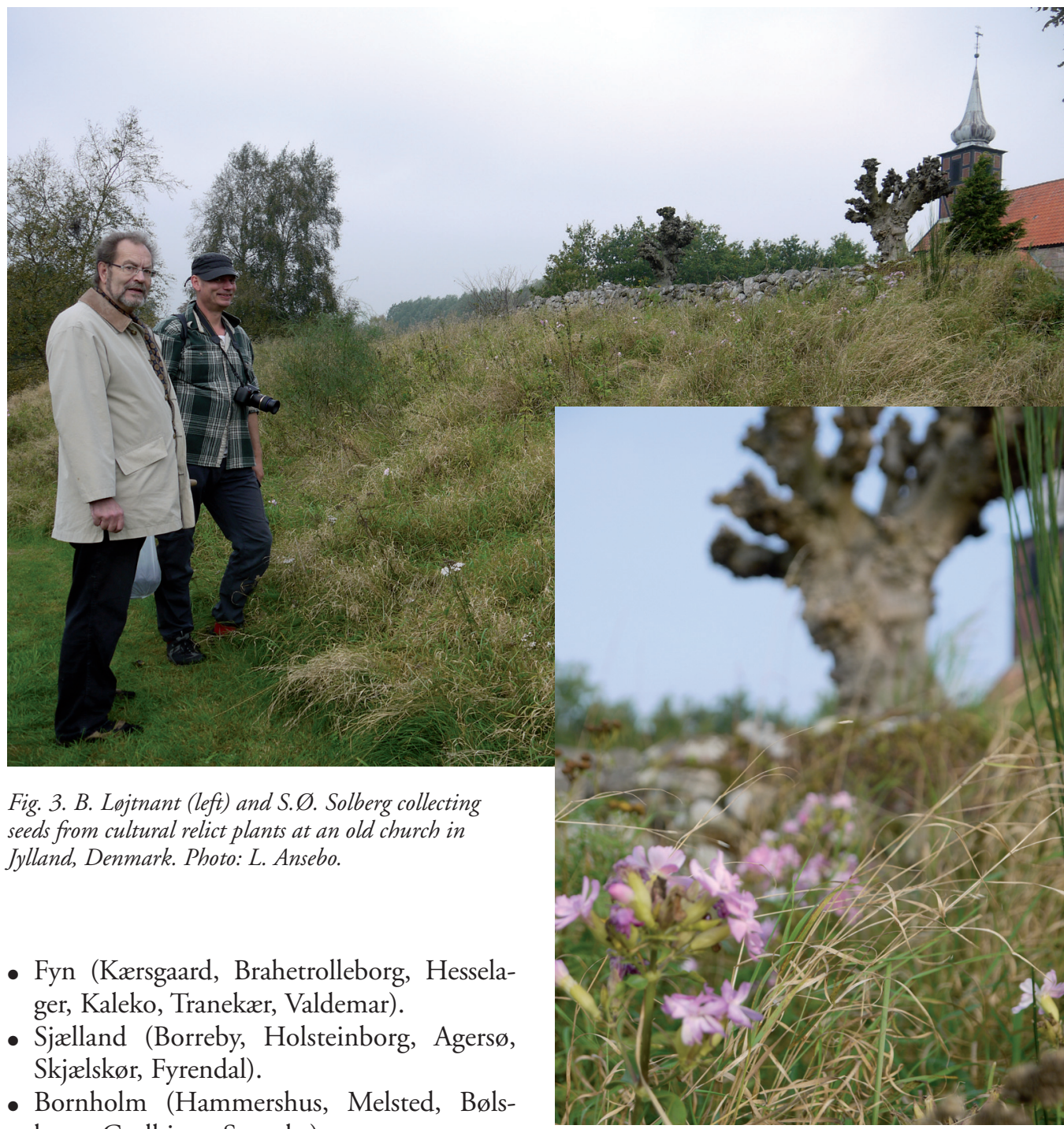
havn, Gudhjem, Svaneke).

- Skåne (Lund, Uppåkra, Håstad, Trollenäs, Malmö).

- Norway (Oslo, Tønsberg).

After collection, the material need to be cleaned, verified, dried (to an internal humidity

Fig. 4. Saponaria officinalis is a quite common cultural relict plant, found in villages and old farms. The plants were used as soap, from where they got their name; "sapeurt" in Norwegian and "sapnejlika" in Swedish. Photo: L. Ansebo. 
Northern Scandinavia (both Northern Sweden, Northern Finland and Northern Norway)

Arabis glabra (Tårnurt/Rockentrav), Aegopodium podagraria (Skvallerkål/Kirskål), Aethusa cynapium (Hundepersille/Vildpersilja), Alliaria petiolata (Laukurt/Löktrav), Allium schoenoprasum (Grasløk/Gräslök), Anchusa officinalis (Oksetunge/Oxtunga), Anemone nemorosa (Hvitveis/ Vitsippa), Angelica archangelica (Fjellkvann/Kvanne), Anthemis tinctoria (Gul gåseblom), Arctium lappa (Storborre/Stor Kardborre), Bistorta major (Ormrot/Stor Ormrot), Brassica campestris (Akerkal), Carum carvi (Karve/Kummin), Daphne mezereum (Tysbast/Tibast), Fumaria officinalis (Jordrøyk/Jordrök), Geranium sylvaticum (Skogstorkenebb/Midsommarblomster), Lamium album (Dauvnesle/ Vitplister), Myrris Odorata (Spansk kjørvell Spansk körvel), Nepeta cataria (Kattemynte/Kattmynta), Oenothera biennis (Nattlys/Nattljus), Ornithogalum umbellatum (Fuglestjerne/Morgonstjärna), Papaver rhoeas (Kornvalmue/Kornvallmo), Paris quadrifolia (Firblad/ Ormbär), Pastinaca sativa (Pastinakk/Palsernacka), Petasites hybridus (Legepestrot/Pestskråp), Polemonium caeruleum (Fjellflokk/ Blågull), Primula veris (Marinøkleblom/Gullviva), Primula elatior (Hagenøkleblom/ Lundviva), Prunus padus (Hegg/Hägg), Ribes nigrum (Solbar/Svarta vinbär), Ribes rubrum (Villrips/Skogsvinbär), Ribes uva-crispa (Stikkelsbar/Krusbär), Rosa majalis var. foecundissima (Kanelrose/Kanelros), Rosa pimpinellifolia (Trollnypel Pimpinellros), Rubus idaeus (Bringebar/Hallon), Rumex longifolius (Høymolel Gårdsskräppa), Rumex obtusifolius (Byhøymolel Tomtskräppa), Sanguisorba officinalis (Blodtopp), Saponaria officinalis (Såpeurt) Såpnejlika), Sedum acre (Gul fetknopp), Sedum album (Kvitbergknapp/Vit Fetknopp), Sedum telephium ssp. Telephium (Smørbukk/Kärleksört), Symphytum asperum (Fôrvalurt/Fodervallört), Symphytum officinale (Valurt/Äkta Vallört), Urtica dioica (Stornesle/Brännäsla), Valeriana officinalis (Legevendelrot/Läkevänderot), Valerianella locusta (Vårsalat/Vårklynne), Verbascum nigrum (Mørkkongslys/Mörkt Kongsljus), Verbascum thapsus (Filtkongslys/Kugsljus),

Veronica longifolia (Storveronika/Strandveronika), Vinca minor (Gravmyrt/Vintergröna).

Additional species only for Northern Sweden: Onopordun acanthium (Ulltistel) and Verbascum lychnitis (Melkongslys/ Grenigt Kungsljus).

Additional species only for Northern Norway: Aconitum napellus (Venusvogn/Äkta Stormhatt), Anemone ranunculoides (Gulveis/Gulsippa), Conopodium majus (Jordnøtt/Nötkörvel), Malus sylvestris (Villapal/Vildapel), Origanum vulgare (Bergmynte/Kungsmynta), Peucedanum ostruthium (Meisterrot/Mästerrot), Primula vulgaris (KusymrelJordviva), Sedum rupestre (Broddbergknapp/Stor Fetknopp), Veratrum album (Hvit Nyserot/Vit Nysrot).

\section{Iceland}

Angelica archangelica (Etihvönn), Anthemis tinctoria (Gult gasablóm), Brassica campestris (Akurkál), Campanula glomerata (Höfuðklukka), Carum carvi Kúmen), Geranium sylvaticum Blágresi), Lamium album (Ljósatvítönn), Myrrhis odorata (Spánarkerfill), Paris quadrifolia (Ferlaufasmári), Petasites hybridus (Hjartablaðka), Polemonium caeruleum (Jakobsstigi), Ribes nigrum (Svört hlaupber), Ribes rubrum, Ribes uva-crispa, Rosa pimpinellifolia (Pyrnirós), Rumex longifolius (Njoli), Rumex obtusifolius, Sanguisorba officinalis (Blóðkollur), Sedum acre (Helluhnoðr), Symphytum officinale, Urtica dioica (Sérbýlisnetla), and Valeriana officinalis (Garðabruða).

According to Löve (1945) also: Allium oleraceum (Villilaukur). 


\section{Faroe Islands}

Aegopodium podagraria (Skvalderkål), Angelica archangelica (Kvan), Brassica campestris (Ager-Kål), Carum carvi (Kommen), Geranium sylvaticum (Skov-Storkenab), Mentha spicata (Grønnmynte), Myrrhis odorata (Sødskarm), Primula vulgaris (Storblomstret Kodriver), Rumex obtusifolius (Butbladet Skrappe), Rumex longifolius (By-Skrappe), Tanacetum vulgare (Rejnfan), Urtica dioica (Stor Nelde).

According to Guldager Christensen (2009) also: Achillea millefolium (Alm. Røllike), Achillea ptarmica (Nyse-Røllike), Plantago major (Glat Vejbred), Ranunculus ficaria (Vorterod), Tanacetum sp. (Melkebøtte), Vicia cracca (Muse-Vikke).

\section{Greenland}

Angelica archangelica (Kvan), Brassica campestris (Ager-Kal), Carum carvi (Kommen), Cirsium heterophyllum (Forskelligbladet Tidsel), Geranium sylvaticum (Skov-Storkenab), Ribes rubrum (Ribs), Rubus idaeus (Hindber), Rumex longifolius (By-Skreppe), Rumex obtusifolius (Butbladet Skreppe), Sambucus nigra (Almindelig Hyld), Sedum acre (Bidende Stenurt), Urtica dioica (Stor Nelde), and Verbascum thapsus (Filtbladet Kongelys).

According to Böcher et al. (1978) also: Plantago major (Glat Vejbred), Rumex acetosa (Almindelig Syre) and also Taraxacum sp. (Malkebøtte).

Table 1. Species with the potential of being a CRP in Northern Norway, Northern Sweden, Northern Finland, Iceland, Faroe Islands and Greenland. Plant names are given in Latin followed by one or more Nordic languages.

of approx. 5\%), packed, and stored (in freezers at $\left.-18^{\circ} \mathrm{C}\right)$. The data must also be stored, and with the seeds made available to the public. To ensure the quality and quantity of the material, germination tests and multiplication must be carried out. Knowledge about how to germinate and how to multiply CRP is not always present, and germination and regeneration protocols need to be established.

\section{CONCLUDING REMARKS}

Several questions remain to be answered. Whose responsibility is the cultural relict plants? Whose responsibility is the in situ conservation, and how is it possible to get all stakeholders involved? It is vital that the owners are made aware of the complexity of cultural relict plants. Furthermore, the owners and the practitioners of the places need knowledge and resources to carry out management plans and conservation. Ethno-botany, archaeology, horticulture and other disciplines with knowledge about traditional cultivation and use of plants should be involved. The actors and the authorities must see CRPs as part of our cultural and natural heritage. Conservation of CRPs can only be successful with a trans-disciplinary approach and with the inclusion of all the parties involved.

\section{LITERATURE}

Benediktsson, J.: Gísli Magnuisson (Visi-Gísli), Avisaga, Ritgerðir, Bref. Hinu Íslenzka Fræðafélagi í Kaupmannahöfn, Ísafoldarprentsmiðja H.F.: Reykjavík, 1939.

Bjerregaard, T. H.: Hammershusklippens flora: http://bornholmsnatur.naturstyrelsen.dk (last retrieved January 2013). 
34 Böcher, T. B. Fredskild, K. Holmen \& K. Jakobsen: Gronlands flora. P. Haase Forlag: Copenhagen, 1978.

CBD 1992: Convention on Biological Diversity. United Nations: http://www.cbd.int (last retrieved December 2012).

Centrum för biologisk mångfald 2013: Verksamhet: http://www.slu.se (last retrieved April 2013).

Cultural Heritage Act: Act of 9 June 1978 No.50 concerning the cultural heritage ('Kulturminneloven"): http://www.lovdata.no (English translation $\mathrm{UiO}$, last retrieved December 2012).

Den virtuella floran: http://linnaeus.nrm.se (last retrieved December 2012).

Direktoratet for Naturforvaltning: Naturmangfold: http://www.dirnat.no/naturmangfold (last retrieved January 2013).

Flora of Iceland: http://www.floraislands.is (last retrieved December 2012).

FOR-2010-10-01-1319: Forskrift om fredning av SorGjeslingan kulturmiljo, Vikna kommune, NordTrøndelag: http://www.lovdata.no (last retrieved January 2013).

Guldager Christiansen, H. \& A. M. Fosaa: 'Færøernes ældste kulturplanter”. Fróðskaparrit 57, 2009: 128-148.

Hafsteinsson, S. B.: 'Forord". Nordisk Museologi. No 1, 2010: 2.

Høeg, O. F. A: Planter og tradisjon. Universitetsforlaget: Oslo, 1976.

ITPGRFA 2002: International Treaty on Plant Genetic Resources for Food and Agriculture: http://www.planttreaty.org (last retrieved January 2013).

Lange, J.: "Lad urtene gro", Tidsskriftet SKALK. No. 2, 1966: 29-30.

Lange J.: Kulturplanternes indforselshistorie i Danmark-indtil midten af 1900-tallet. DSR Forlag: Frederiksberg, 1999.

Larsson, I.: Millefolium, rölika, näsegräs - Medeltidens svenska växtvärld i lärd tradition. KSLA: Stockholm, 2010.
Larsson, I., P. A. Åsen, S. Kristjánsdóttir and K. Lundquist, K: Medeltida klostergrunder på Island - vegetation och flora, kultur och reliktväxter. Sveriges lantbruksuniversitet. Landskap trädgård jordbruk rapportserie 2012: 12.

Lind, J.: Om lageplanter i danske klosterhaver og klosterbøger. Henrik Koppels Forlag: København, 1918.

LOV 2007-06-29 nr 89, Kulturloven: Lov om offentlege styresmakters ansvar for kulturverksemd: http://www.lovdata.no (last retrieved December 2012).

Lundquist, K.: 'Medeltida klostergrunder på Island vegetation och flora, kultur- och reliktväxter, samtida växtnamn". Sveriges lantbruksuniversitet. Landskap trädgård jordbruk fakultetens faktablad. No 7, 2010: 1-4.

Løjtnant, B.: "Registrering af græskirkegårde i Danmark." Fra Kvangard til Humlekule. No 36, 2006: 21-45.

Løjtnant, B: 'Levende levn”. Tidsskriftet SKALK. No. 4, 2007a: 11-15.

Løjtnant, B.: 'Kirkens grønne guide". Gejrfuglen (Østjysk Biologisk Forening). 43, No 3, 2007b: $1-16$.

Løjtnant, B., H. Guldager Christensen, N. Faurholdt \& B. Prehn: "In-situ bevaring af fortidsminder". URT (Dansk Botanisk Forening). 19 (4) 1995: 112-117.

Löve, A.: Islenzkar jurtir. Ejnar Munksgaard Kaupmannahöfn: Iceland, 1945.

Martinsson, K. \& S. Ryman: Blomboken - bilder ur Olof Rudbecks stora botaniska verk. Prisma: Stockholm, 2008.

Ministry of the Environment, Norway: Department of Cultural Heritage and Cultural Environments: http://www.regjeringen.no/en/dep/md (last retrieved January 2013).

Molbech C.: Henrik Harpestrengs Danske Lagebog fra det trettende Aarhundrede. København, 1826.

Mossberg B. \& L. Stenberg: Den nya nordiska floran 
(Swedish edition). Wahlström \& Widstrand: Stockholm, 2003.

Museumsloven: LBK nr 1505 af 14/12/2006, http://www.retsinformation.dk (last retrieved January 2013).

Persson, E.: 'What's in a name?" In Sources to the History of Gardening: Three Interdisciplinary Seminars 2010-2012 Arranged by the Nordic Network for the Archaeology and Archaeobotany of Gardening (NTAA). Sveriges lantbruksuniversitet. Landskap trädgård jordbruk, rapportserie (in progress 2013).

Persson E., L. Ansebo \& S. Ø. Solberg: "Cultural Relict Plants in the Nordic Area". In Sources to the History of Gardening: Three Interdisciplinary Seminars 2010-2012 Arranged by the Nordic Network for the Archaeology and Archaeobotany of Gardening (NTAA). Sveriges lantbruksuniversitet. Landskap trädgård jordbruk, rapportserie (in progress 2013).

Poulsen, G., S. Ø. Solberg \& B. Løjtnant: 'Reliktplanter - bevaring af levende kulturminder". Skriftserie fra Dansk Landbrugsmuseum. No $7-$ 2010: 84-88.

Solberg, S. Ø., E. Persson \& L. Ansebo: Reliktplanter - levende fortidsminner. Nordisk genresurssenter: Alnarp, 2012.

Stortingsmelding nr. 93 (1971-72): http://www.regjeringen.no/nb/dep/kud/dok/nouer/1996/nou1996-7/11/8.html?id=339953 (last retrieved January 2013).

Tunón, H. \& M. Byström: Naptek - Nationella programmet for lokal och traditionell kunskap relaterad till bevarande och hallbart nyttjande av biologisk mångfald. Årsrapport 2006, Centrum för biologisk mångfald: Uppsala, 2007.

Åsen P. A.: "Plants of Possible Monastic Origin, Growing in the Past or Present, at Medieval Monastery Grounds in Norway". In Plants and Culture: Seeds of the Cultural Heritage of Europe. Edipuglia: Italy, 2009, s. 227-238.
*Svein Øivind Solberg, senior scientist

Address: Nordic Genetic Resource Center, Box 41, SE-230 53 Alnarp, Sweden

E-mail: svein.solberg@nordgen.org

*Line Breian, PhD student

Address: Tromsø Museum, Lars Thørings veg 10, NO-9006 Tromsø, Norway

E-mail:line.breian@uit.no

*Lena Ansebo, senior scientist

Address: Nordic Genetic Resource Center, Box 41, SE-230 53 Alnarp, Sweden

E-mail: lena.ansebo@nordgen.org

*Erik Persson, senior scientist

Address: Swedish University of Agricultural Sciences, The Department of Landscape Architecture, Planning and Management, SE-230 53 Alnarp, Sweden

E-mail: erik.persson@slu.se 